\title{
STAKEHOLDER VIEWS ON SUSTAINABLE COMMUNITY-BASED ECOTOURISM: A CASE OF THE PAGA CROCODILE PONDS IN GHANA
}

\author{
Rapael Ane ATANGA* \\ University of Johannesburg, School of Tourism and Hospitality, Bunting Road Campus \\ 2006 Johannesburg, South Africa, e-mail: ratanga@uj.ac.za; raptanga@yahoo.co.uk
}

\begin{abstract}
Citation: Atanga, R.A. (2019). STAKEHOLDER VIEWS ON SUSTAINABLE COMMUNITYBASED ECOTOURISM: A CASE OF THE PAGA CROCODILE PONDS IN GHANA. GeoJournal of Tourism and Geosites, 25(2), 321-333. https://doi.org/10.30892/gtg.25204-362
\end{abstract}

\begin{abstract}
This study analysed tourism at the Paga Crocodile Ponds in the Upper East Region of Ghana as a basis to evaluate its potential for sustainable community-based ecotourism development. The study employed qualitative case study approach, using data from secondary and primary sources that involved in-depth interviews with key actors in the tourism sector of the community in Ghana. Results of the study suggest that tourism in the community is in its developing stage. The Paga Crocodile Ponds attract international and domestic tourists, and tourism influences the socio-cultural, economic, and environmental livelihood of the community. The research found that the ponds were silted and experiencing threats of drought and competition from other uses of the water. Tourism at Paga is mainly managed by the traditional community leaders with insufficient tourism infrastructure and therefore needs support from government and other stakeholders. The results suggest that a sustainable community-based ecotourism development in the community require improvement in stakeholder involvement, environmental sanitation and water level of the ponds.
\end{abstract}

Key words: Ecotourism, sustainable community-based ecotourism, Paga Crocodile Ponds

\section{INTRODUCTION}

This paper investigated sustainable community-based ecotourism development in Paga towards making the community a sustainable tourism destination in the pan-African context. Tourism contributes greatly to socio-economic development (Rogerson, 2007, 2014; Telfer \& Sharpley, 2008; WTTC, 2018). The World Travel and Tourism Council (WTTC, 2015) argues that the global travel and tourism generated 122,000 jobs in 2014 alone, which translated into $2.2 \%$ of the total employment and this was expected to increase to $2.3 \%$ by 2015 . Tourism is a practical means for development in developing countries, with sustainable community-based ecotourism as a tool for social, economic, and environmental wellbeing of localities (Scheyvens, 1999; Asiedu, 2002; TIES, 2018).

\footnotetext{
* Corresponding author
} 
Ecotourism is one alternative forms of tourism described as the fastest growing in the tourism industry and useful for the development of less developed nations. It is a source of rural livelihood and a promoter of sustainable development agenda. But, depending on how it is managed, ecotourism can induce positive and negative social, economic and environmental impacts (Wearing \& Neil, 1999; Weaver, 2009; Das \& Chatterjee, 2015; Woldu, 2018). Consequently, sustainable community-based ecotourism is advocated as an approach to managing tourism for the benefit of the local communities without degrading the local culture, economy and environment. Tourism stakeholders in communities are the individuals directly engaged in tourism management with authority.

Studies about ecotourism in Ghana have not focused on in-depth understanding and analysis of tourism at the Paga Crocodile Ponds using a sustainable communitybased ecotourism model. Asiedu (2002) considered the potentials of ecotourism for rural development in Ghana whereas Cobbinah (2015) studied local community understanding of ecotourism of the Kakum National Park in Ghana and concluded that there is need for further studies in the field. Acquah et al. (2017) studied the sociocultural impacts of ecotourism on park-adjacent communities of the Kakum National Park, Shai Hills, and Mole Game Reserve in Ghana. Eshun \& Tonto (2014) focused on the benefits and conflicts of ecotourism in communities around Kakum National Park. Amuquandoh (2010) researched on lay concepts of tourism in the Lake Bosomtwe Basin while Eshun \& Tagoe-Darko (2015) considered ecotourism from postcolonial perspectives. These studies focused on popular tourism destinations in Ghana. Additionally, there is campaign for more research on sustainable community-based ecotourism in developing nations (Dangi \& Jamal, 2016) and this study fits well into filling this gap. This research analyses the views of stakeholders about tourism at the Paga Crocodile Ponds in Ghana from a sustainable community-based ecotourism perspective. The paper argued that tourism activities at Paga have social, economic, cultural and environmental impacts with a potential for a sustainable community-based ecotourism development. Characteristics of tourism and its organisation at the ponds are described. This paper consists of introduction to specify the context, problem and objectives of the research. The other sections focused on sustainable community-based ecotourism concept, research methods, discussion of results, conclusions and recommendations.

\section{Aim and research objectives}

The aim of this study is to contribute to research on sustainable community-based ecotourism development. The specific objectives of the study are to:

1. Analyse the characteristics of tourism of the Paga Crocodile Ponds in the context of sustainable community-based ecotourism concept.

2. Evaluate the potential for a sustainable community-based ecotourism development of the Paga Crocodile Ponds.

\section{THE STUDY AREA}

Paga is the capital of the Kasena-Nankana West District (KNWD) in the Upper East Region of Ghana (Figure 1). Paga is a multi-religious town with Christianity, Islam and African Traditional Belief systems co-existing (KNWD, 2009). The traditional political head and custodian of the community is the local chief. Agriculture and smallscale businesses characterised the community with poor farm yields due to infertile soils and unreliably short rainfall periods from May to November annually. With savannah climatic conditions, dugout dams and wells are useful for irrigation farming in the dry season in the community. Paga and its surrounding villages have a population of about 17,250 (KNWD, 2009). With poor economic activities, levels of employment and poverty are high in the community. 

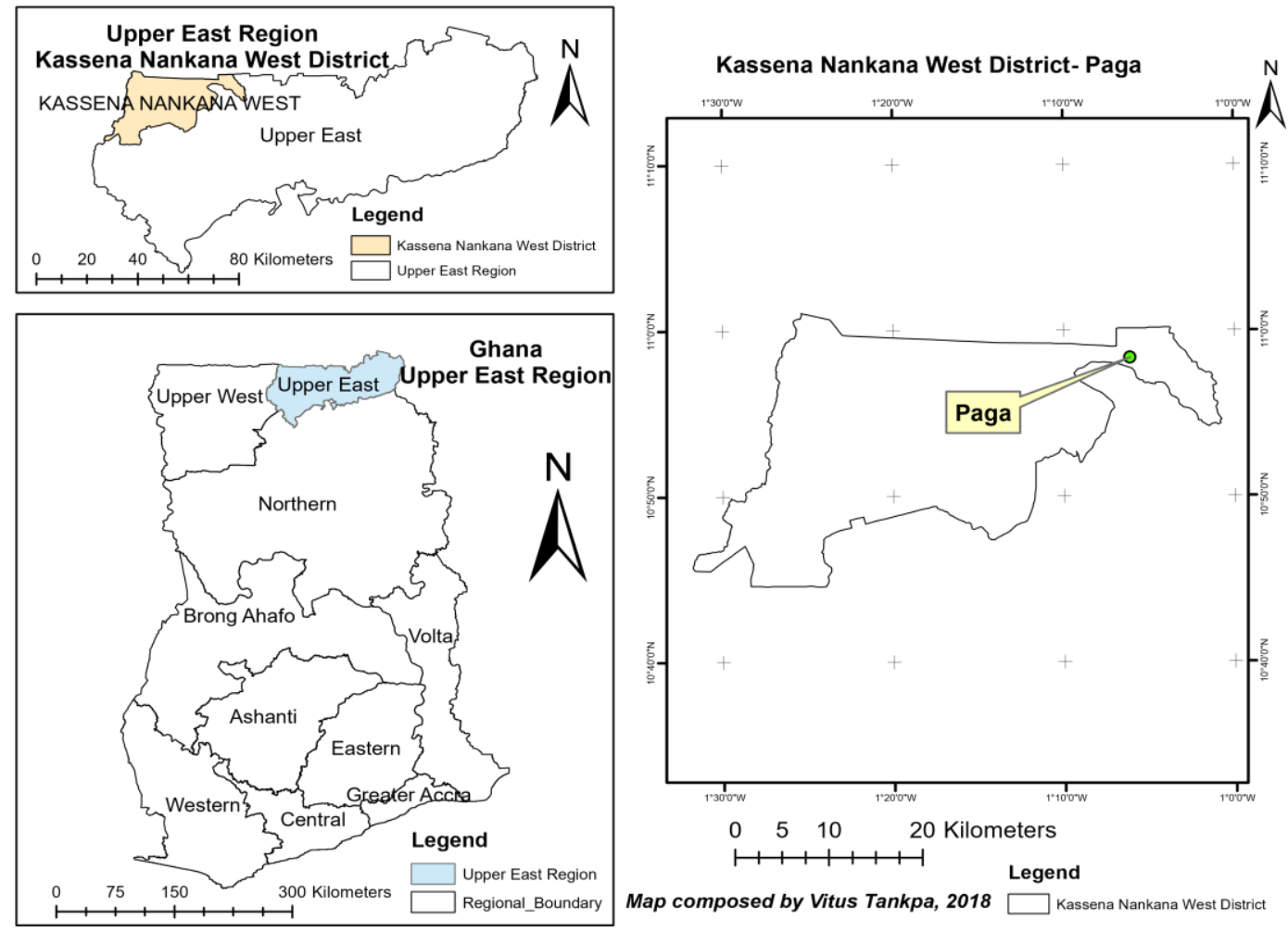

Figure 1. Map of the Study Site (Source: Vitus Tankpa, 2018)

\section{CONCEPT OF SUSTAINABLE COMMUNITY-BASED ECOTOURISM}

Sustainable community-based ecotourism seeks to address the ills of mass tourism (Weaver, 2009). The concept of tourism has shifted from mass tourism to alternative tourism due to the negative impacts of the former on society (Wearing \& Neil, 1999; Weaver, 2009). Alternative tourism involves all responsible tourism including ecotourism, rural tourism and community-based tourism. Alternative tourism is to sustain economic, social, cultural and environmental values without neglecting tourists interests. Moreover, it is part of the sustainable development agenda of Brundtland Report, 1987. Ecotourism has no precise definition. Fennell (2001) found 85 definitions of ecotourism with many more left unidentified. However, the author indicated that the common features of the concept as nature-based, conservation, culture, benefit to locals and education. Ceballos-Lascurain defines ecotourism as "travelling to relatively undisturbed or uncontaminated natural areas with the specific objective of studying, admiring, and enjoying the scenery and its wild plants and animals as well as any existing cultural manifestations (both past and present) found in these areas" (Boo, 1990: 2).

This definition suggests a common conceptual basis and practice of ecotourism. Ecotourism supports conservation, livelihoods, environmental education and sustainable development of destination communities, but evidence shows that this is not always the case (Coria \& Calfucura, 2012). Sometimes it causes environmental and cultural degradation, neglect of local communities, conflicts among stakeholders and economic leakages (Ojeda, 2012; Eshun \& Tagoe-Darko, 2015; Tichaawa \& Mhlanga, 2015). Community-based ecotourism is in response to problems of ecotourism (Scheyvens, 1999). The focus of the concept is to involve local communities in tourism management 
and benefits while conserving local environment and culture for the interests of tourists. Conversely, other scholars argue that ecotourism is sometimes used as a marketing tool with contempt of its core values and as well controlled by cooperate bodies and local elites to the neglect of local communities (Coria \& Calfulcura, 2012; Cobbinah, 2015). The term community is used here to signify a group of people with common interest and attachment to a common resource in a geographical location. Local communities need to participate in tourism development process and its benefits (Richards \& Hall, 2000). This study considers tourism stakeholders individuals involved in tourism management.

\section{MATERIALS AND METHODS}

A case study is an investigation of a phenomenon within its context for indepth understanding (Yin, 2009). A qualitative approach allows for detail comprehension tourism at the crocodile ponds from secondary and primary data sources. A gatekeeper mediated the data collection at Paga. This strategy effectively established rapport between the researcher and the research participants. The data were obtained from expert interviews, observations, comments of tourists and minutes of the local tourism board meetings. Secondary data from historical documents and comments of tourists, expressing their touristic experiences at the ponds. Tourists expressed their satisfaction, dissatisfaction and suggestions for tourism improvements at the site. The following research participants were interviewed after a successful traditional community entry process. The representatives of the Paga Chief (TS1), Kasena-Nankana West District Assembly Planning Officer (TS2), Achala Village (TS3), District Tourism Board (TS4), two tour guides (TS5, TS6), Kubbs Lodge (TS7), Paga Motel (ST8), Paga Community Tourism Development Committee (TS9) and Zenga Community (ST10) as experts in the tourism sector. In all, ten in-depth interviews were conducted with an average duration of 30-45 minutes each. A semistructured interview guide with open-ended questions was used for the data collection. This allowed the researcher to obtain detailed data from the research participants (Cook \& Crang, 2007). The interviews covered themes on the socio-cultural characteristics of tourism, tourism activities and organisation, economic, social, and environmental impacts in the community (Lee, 2013). Potentials for sustainable community-based ecotourism development were explored. A purposive and snowball sampling techniques were used to identify the research participants. Thematic content analysis was applied to analyse the data and the results were interpreted narratively. The data were manually organised into themes according to the research objectives. The interviews were transcribed verbatim and coded according to the research themes. The quotations from secondary and primary data are interpreted narratively to support the research objectives.

\section{RESULTS AND DISCUSSION}

\section{Tourism activities and organisation}

The spatial distribution of tourism is crucial to understand for socio-economic development (Hall, 2013; Rogerson, 2014). This research revealed that the Paga Crocodile Ponds as well as Pikworo Slave Camp, the Chief Palace, the Market Square and the Achala Village Architecture attract tourists in Paga. The Chief Crocodile Pond and the Zenga Crocodile Pond are 1 kilometer apart. The results indicate that the two crocodile ponds were small water bodies which have been constructed in the second half of the 2oth century. The respondents confirmed in the interviews that: "the construction was needed to expand the ponds to contain the increasing number of crocodiles" (TS5). This further supports the argument that ecotourism contributes to environmental conservation (Brundtland Report, 1987; Weaver, 2009). The Nania Gardens are botanical gardens with variety of ornamental plants. 
The research findings confirmed that the crocodiles are a totem for the natives of Paga as the following quotation illustrates: "The crocodiles are the souls of our ancestors and are our souls too. We believe that in Paga when you kill a crocodile you have killed a human being and it has been happening. It is a taboo in Paga to kill, eat crocodile or keep its body parts" (ST1). History shows that, the crocodiles are associated with the first settler of Paga, Nave, who immigrated with the crocodiles from Tampela to Kampala in Burkina Faso and finally settled at Paga in Ghana. The crocodiles are a symbol of the people and a shrine for unity and protection. Similar to findings of other studies, African traditional belief systems are linked to nature and animals (John-Parson, 1958; RimRukeh et al., 2013). The monkeys at the Monkey Sanctuary in Boabeng and Fiema have similar reverence as the crocodiles at Paga (Appiah-Opoku, 2007).

Ecotourism involves interaction with nature and appreciation of culture and history communities (Boo, 1990; Weaver, 2009; TIES, 2018). This research shows that the tourists offer live chicken to crocodiles and interact with them. The reseach findings illustrate that: "When the tourists come, they sit on the crocodile, hold its tail, they play with the crocodiles and take pictures of the environment. Tourists listen to the history of the ponds and the community. Tourists are always fascinated by the way they sit on the crocodiles and the friendly nature of the animal" (TS6). Tour guides play important role in tourism development (Cetinkaya \& Oter, 2016). Six tour guides working at the Paga Zenga Crocodile Pond, were employed by the chief and traditional leaders in the community. The roles of the tourguides are to call out the crocodiles, narrate history of the tourism, give chicken to crocodiles, and guide tourists around to understand the sites. The research findings indicate in the following quotation that: "The tour guides are trained to call out the crocodiles for tourists and interpret the history of the community and the crocodiles" (TS10). Tour guides need to be conversant with the history of the community and the crocodiles. The results show that chicken for the crocodiles is controlled as the following quotation demonstrates: "all tourists are required to buy live fowls at the ponds in order to ensure the safety of the crocodiles" (ST1). This safety measure helps to conserve the crocodiles and creates market for local fowl vendors. The ponds attract domestic and international tourists. In the year 2010 the fee for domestic tourist was GHC 2.00 while an international tourist paid GHC4.00 (GHC = Ghana Cedis). In the year 2018, a domestic tourist pays about GHC7.00 while an international tourist pays GHC15.00. This difference in the fees is to provide an incentive for domestic tourists.

The research findings show tourism ownership and management. The royal family owns and manages the Chief Pond whereas the Paga Zenga community owns and manages the Zenga Pond. Income from the Chief Pond is for maintenance of the ponds, sacred responsibilities, and payment of tour guides and that from the Zenga is used for community development. The results confirmed that: "The money we collect from the tourists at the Zenga Crocodile Pond is divided into two equal parts; half of it is used for the development of the community and the other half of the money is used for paying the tour guides and maintaining the pond" $\left(\mathrm{TS}_{5}\right)$. The research shows that, government, nongovernmental organisations and private sector involvement in tourism is poor and it is managed by the traditional community leaders. Contrarily, other studies show that government officials and corporate tourism organisations (Coria \& Calfucura, 2012; Eshun \& Tonto, 2014). The research findings show that tourism stakeholders met with the Paga Chief, the district Security Sub-Committee, hotel operators and tour guides to visit the tourism sites in community (Tourism Development Sub-Committee Minutes, February 20, 2010). The policy guide is to improve tourism management and development in Paga through stakeholder involvement, tour guide education, sanitation and environmental management of the ponds. The stakeholders in tourism development 
were specified. The research findings illustrate that: "Besides the chief and the district assembly, the other stakeholders are the Ghana Tourist Board and local Tourism Development Sub-Committee. As of now, we do not really have strong NGOs and the private sector involvement concerning the development of the tourism sector" (ST3).

A few organisations have interest in tourism development in the community and these included Nature Conservation Research Centre (NCRC), Paga Ecotourism Committee, the American Peace Corps group and some individuals (KNWD, 2009). The results showed that tourism infrastructure is poor. This is in line with the general poor tourism infrastructure in Ghana (Yankholmes \& Akyeampong, 2010). The respondents explained in the interviews that: "We have accommodation and catering services, and poorly constructed road. Almost every year, we have to rehabilitate the road to the pond" (ST2). The information above emphasises the growing yet undeveloped, state of the tourism infrastructure in the community.

The findings confirmed that tourism occurs throughout the year. The interviewees illustrated that: "Tourism activities here are all year round and I do my tour guiding activities every day. ...tourist numbers have been increasing over the past few years. The tourists come from different socio-cultural backgrounds; Ghanaians and non-Ghanaians, rich and poor as well as students" (ST5). Evidence of tourist experiences at Paga showed a mixed feeling of satisfaction, dissatisfaction and comments for improvements. Satisfactory comments describe the destination as good, very good, interesting, impressive, awesome, wonderful, excellent, lovely, nice, fantastic, fabulous, historic, and attractive experiences. A few tourists had good experiences but want further improvements. These includes lovely crocodiles but get a recreational centre; good experience with the crocodiles but road to the pond untarred.

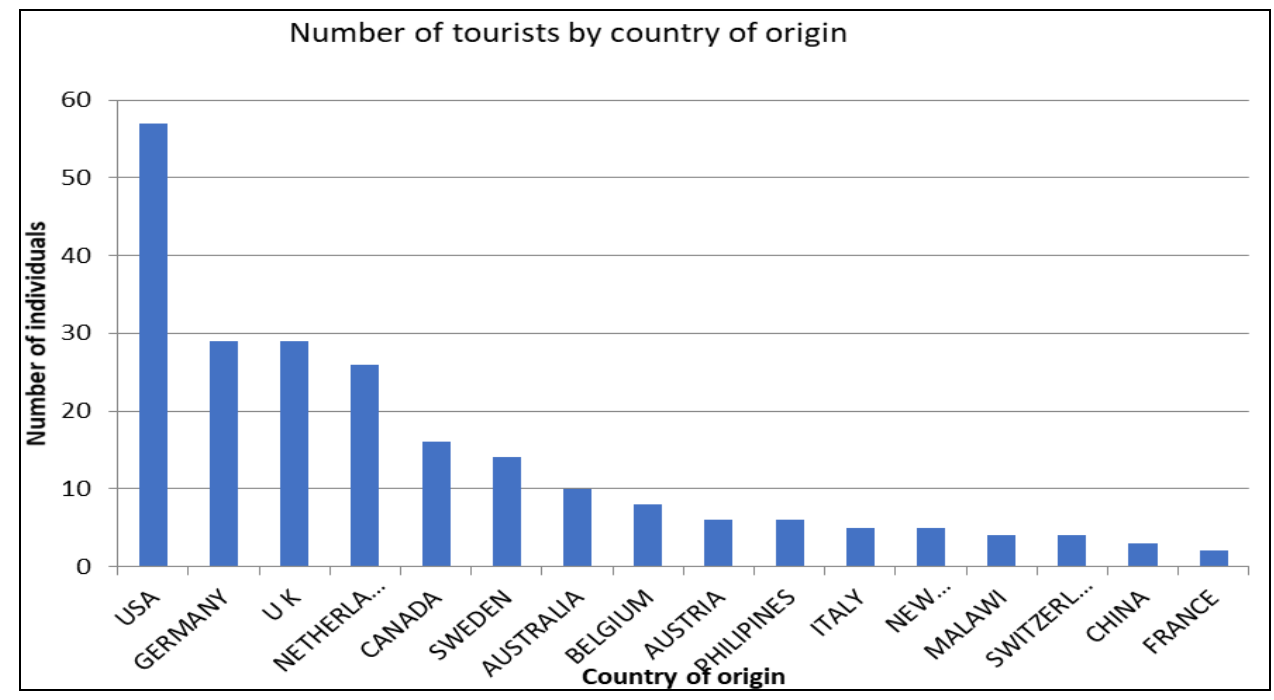

Figure 2. Shows International Tourist Origins to the Community

(Source: Adapted from Paga Zenga Crocodile Pond Tourism Visitor Book, 2009/2010)

Unsatisfactory comments of tourist bad experiences include high fees, no development, site undeveloped and tour guides unfriendly. This finding matches with the comment from the tour guide that the tourists have good impression about the tourism at the sites. All the fifteen letters that were read had expressions of nice experiences at the sites (Paga Zenga Crocodile Pond Tourism Visitor Book, 2009/2010). 
Whereas the comments consisted of both positive and negative experiences, the letters contained only positive experiences. Countries of origin of international tourists to the community were visible in the tourist book as shown in Figure 2.

The results show similar trends of tourist arrivals to the Zenga Crocodile Pond for the years of 2011, 2012, 2013, 2015, 2016 and 2017. In the year 2011, a total of 4,653 (4,265 domestic and 388 international) tourists visited the site. For the year 2012, a total of 5690 (5226 domestic and 464 international) tourists visited the Zenga pond. In the year 2013, the total number decreased to 3,141 (2947 domestic and 194 international) tourists. Figures for the year 2014 were not available. The year 2015 had 3,026 (2808 domestic and 218 international) tourists. The total tourists arrived at the Zenga pond in the year 2016 was 6,370, consisting of 5958 domestic and 412 international tourists. The number of tourists for the year 2017 was $8292(7945$ domestic and 347 international) tourists. The figures indicate a decline in the number of tourist arrivals to the ponds. Several reasons might have been responsible for this decline, but no apparent explanation was identified. As in other African tourism destinations, the international tourists typically come from the developed nations, with the USA recording the highest number (Williams, 2009). One African country is on the list, which supports the notion that tourism is a popular activity for western middleclass people. The ability to speak multiple international languages can play a role in the activities of a tour guide and this was discussed in the interviews.

The respondents confirmed that English is the only international language used by the tour guides. Rylance (2008: 34) states that "language remains a constraint to local economies in accessing the marketplace" and argues that tourism in Mozambique is limited to Portuguese and a recipe for underdevelopment of the sector.

This representation follows Cohen's theory of institutionalised and noninstitutionalised types of tourism, which explains that most tourists of noninstitutionalised tourism destinations are domestic. Tourism at Paga is still at its developing state, and non-institutionalised. The relationship between international tourists and total revenue is positive as a short rise in the number of international tourists leads to a sharp increase in the total revenue and a short fall in international tourist numbers results in a drastic reduction in the total revenue.

\section{Economic, socio-cultural and environmental impacts of tourism}

This research found that tourism in the Paga community has economic, environmental and socio-cultural impacts (Das \& Chatterjee, 2015). These findings are presented in the following sections.

\section{Economic impacts}

The results show that tourism is a source of employment for the people of Paga and revenue for the local government. Tourism promotes small scale businesses in the community. The results match with findings of other studies that a community-based ecotourism is a source of livelihood for the people of tourism destinations (Asiedu, 2002; Williams, 2009; Das \& Chatterjee, 2015; Kuqi, 2018). Tourism is a source of revenue for Paga community. The total revenue for the major tourism sites has increased from GHC 4,022.00 in 2006 to GHC 9154.00 in 2010 as in Ghana currency. The statistics of tourism revenue of the Zenga Crocodile Pond for the years of 2011, 2012, and 2013 were GHC4,717.70, GHC4,954.70 and GHC3,807.00 accordingly. Revenue for the year 2014 was unavailable. The tourism revenue of the same site for the years of 2015, 2016 and 2017 was $\mathrm{GHC} 4,398.00, \mathrm{GHC}_{12,665.00}$ and $\mathrm{GHC} 9,537.00$ respectively. There is a fluctuating trend of increase in revenue and tourist arrivals.

Tourism creates jobs in the community as the results show that the hospitality, tour operation, sanitation and hotel sectors provide jobs for individuals, especially women, in 
the community. This was illustrated in the interviews as follows: "Tourism creates jobs for the tour guides at the crocodile ponds and the hotel attendants. Seventeen workers work full-time in the Kubbs Lodge Hotel, and these include all the employees. As manager of the hotel, I am included because I am equally a worker" (ST7). A moreover, a private waste and sanitation company in Ghana was contracted deal with waste around the ponds. Overall, the findings suggest that, the industry has the potential to employ more people if tourism becomes sustainable in Paga. The research found that tourism supports local means of livelihood. Tourism can be described as sustainable when it integrates into the local economy (Odede et al., 2015; Dangi \& Jamal, 2016). The interviewees recounted the integration of tourism into agriculture in the community as follows: "We buy seedlings of plants from the gardeners to plant around to conserve our dam and provide shade for tourists to rest" (ST8). The tourism integrated into the local economy as it supports irrigation, livestock, fishing and other socio-economic activities.

\section{Socio-cultural impacts}

Studies reveal that tourism induces positive and negative socio-cultural impacts in communities (Urry, 2002; Mugizi et al., 2018). The results of this research show that tourism makes Paga popular internationally and fosters social cohesion among individuals. There was also evidence of training and workshops for empowerment and capacity development of employees in the sector, similar to the findings of Odede et al., (2015). The respondents pointed out in the interviews that "Ghana Tourism Board organises education and tour guide training workshops for us as tour guides. ...we are educated on receiving and interacting with the tourists. We attend these training workshops twice a year" (ST8). The education and training provided can improve the skills of employees in the sector. In agreement to the findings of Cappucci (2016), the results revealed that crocodile tourism at Paga is unique and a cultural identity of the native people. This was illustrated in the interviews is the following quotatation: "Paga is known all over the world and I think this is all through tourism. The people in the community are proud to be called Pagatina; amo ye Paga tu mo; which in Kasem, the local dialect; literally implies the natives of Paga" (ST1). Regarding social cohesion and community development, the results proved that: "Tourism has brought a lot of cohesion to our community. ... certain times, prominent dignitaries visit the pond, and whenever they visit the pond, they come with other government delegations, and a lot of people in the community gather" (ST3). The findings indicate that the income from tourism was used to build a Kindergarten in the community. The chairperson for the Tourism Development Sub-Committee is a female. This shows the participation of women in tourism decision making. The committee sensitises and educates community members about tourism development. Negative social impacts of tourism in the community were not yet obvious. This is not to ascertain that negative social cultural impacts may not exist in the future.

\section{Environmental impacts}

Environmental impacts of tourism in the Paga community were discussed in this research and the findings showed these impacts in the community. Like the findings of Appiah-Opoku (2007) and Rim-Rukeh et al., (2013), environmental impacts of tourism in Paga and practices of conservation management of the ponds were identified in this research. The findings showed specific environmental regulations to conserve the ponds tree planting program, waste management program, and prohibitions of washing clothes and vehicles in the ponds were put in place to ensure that the ponds are maintained. Accordingly, the respondents illustrated in the interviews that: "the chief and his elders make sure that all the people who farm close to the pond and all those who build close to the ponds discontinue their projects" (ST10). Restriction of these activities could reduce siltation of the ponds from soil erosion. Negative environmental impacts from tourism 
activities were not obvious in the community. It was noted that some domestic tourists dropped litter indiscriminately instead of in the waste bins. This assertion suggests poor sensitivity to waste management of these tourists. The impacts outlined in this section contribute to evaluate tourism activities for a sustainable community-based tourism development.

\section{Tourism development challenges}

Richards \& Hall (2000) envisage that development challenges affect the growth of tourism in developing nations. Tourism at Paga faces infrastructural, management, and environmental challenges that affect development of tourism activities. Research emphasised the importance of infrastructure for tourism development (Jovanović \& Ilić, 2016). Tourism infrastructure in the Paga community is poorly developed and some tourists go to the nearby bigger towns, Navrongo and Bolgatanga, to stay overnight. This is considered a disincentive for the hospitality part of tourism in Paga. Similarly, Fuschi \& Evangelista (2017) found that attractive service alternatives in bigger towns is a threat to rural tourism destinations in Pescara, Italy. Consequently, the accommodation industry is relatively unprofitable. The research found that a major threat to crocodile ponds and tourism in the community is drought as this keep lowering the water level of ponds annually as the following quotation from the interviews illustrates: "I am getting to 12 years as a tour guide here and comparing the state of the water level at the previous years of my job and the current state, the drying up of the pond is getting worse. If it is not dredged, it will get to a time the water will dry completely and the crocodiles will go away, and tourism will end" (ST6). The research discovered that record keeping of the crocodile ponds is poor and this makes planning and management unrealistic. The research participants indicate that: "Record keeping at the pond is a big challenge. There is no good record keeping at the pond, I mean statistics" (ST1). Statistics provide data for tourism management and lack of them problems in development planning.

Marketing of the crocodile ponds is important for attracting tourists to the area. This was seen by interviewees as poorly done when the researcher raised it for discussion in the interviews. Brochures, books, calendars, special programmes on radio and television means for marketing tourism in the community. Internet advertisement identified as ineffective. The next section focuses on preliminary evaluation for developing the Paga into a sustainable community-based ecotourism destination.

\section{EVALUATING SUSTAINABLE COMMUNITY-BASED ECOTOURISM AT PAGA}

Table 1 is a summary of the characteristics of tourism in Paga relative to sustainable community-based ecotourism development principles. Environmental conservation is a key principle of sustainable community-based ecotourism. The evidence of tree planting and conservation regulation confirm this principle. Tourism practices are changing towards environmental conservation and stewardship (Baral, 2013; Cobbinah et al., 2015). The tourism stakeholders at Paga made conscious efforts to conserve the ponds as assets for tourism and in honour of the ancestral pledge to safeguard the crocodiles in the community. Similarly, Spenceley (2008) revealed that the government of South Africa implemented environmental conservation policies to prevent indiscriminate deforestation and poaching in tourism destination communities. The participation of local communities in tourism development planning is crucial for sustainable tourism development (Das \& Chatterjee, 2015). Involving the stakeholders in the planning makes them feel part of the community and stewards of the ponds. The Tourism Development Committee of Paga coordinate with community members for tourism development in the community. The results show that the community members participation in tourism decision-making and development planning is important for sustainability. The results also suggest that tourism is managed by the local traditional authority and community elders, indicating little intervention from other 
stakeholders. This finding is contrary to that of Eshun \& Tagoe-Darko (2015) which revealed that locals around the Kakum National Park do not manage tourism of the park.

Spenceley (2007) contended that, mutuality among stakeholders of tourism destination community can attract external support from government and tourism development agencies. Social groups in tourism destination community need to participate in development planning. Spenceley (2007) contended that, mutuality among stakeholders of tourism destination community can attract external support from government and tourism development agencies. Social groups in tourism destination community need to participate in development planning. The contribution of tourism activities to the economic development of the people in tourism destinations is also important for sustainability. Tourism activities have been noted to offer direct and indirect job opportunities for the local people of Paga. All the tour guides come from the local community and most the employees in the restaurants, hotel and other hospitality sectors originate from the local community. This result agrees to the finding of Tichaawa \& Mhlanga (2015) that the CAMPFIRE contributed to livelihood. Kubbs Lodge hotel, the only vibrant hotel in the community, has nineteen rooms. Community involvement and ownership of tourism businesses reduces economic leakages away from the community.

Table 1. Sustainable community-based ecotourism practices and characteristics of tourism at Paga

\begin{tabular}{|c|c|c|c|}
\hline \multicolumn{2}{|c|}{ Sustainable Ecotourism Principles \& Factors } & \multicolumn{2}{|c|}{ Tourism Characteristics in Paga } \\
\hline Principle & Factors & $\begin{array}{c}\text { Sustainable } \\
\text { Characteristics }\end{array}$ & $\begin{array}{l}\text { Unsustainable } \\
\text { Characteristics }\end{array}$ \\
\hline $\begin{array}{c}\text { Economic } \\
\text { Sustainability }\end{array}$ & $\begin{array}{l}\text { Economic benefits: Job and } \\
\text { livelihood opportunities, } \\
\text { economic integration, growth } \\
\text { of local industries, income, } \\
\text { and revenue generation. Others } \\
\text { includes reinvestment, records } \\
\text { keeping and tourism marketing }\end{array}$ & $\begin{array}{l}\text { Employment of local } \\
\text { people } \\
\text { Local economic } \\
\text { integration \& revenue } \\
\text { Development of } \\
\text { small and medium } \\
\text { scale enterprises }\end{array}$ & $\begin{array}{l}\text { Poor records keeping, } \\
\text { marketing, revenue } \\
\text { management and } \\
\text { reinvestment } \\
\text { Inadequate } \\
\text { monitoring }\end{array}$ \\
\hline $\begin{array}{l}\text { Enviro } \\
\text { Sustai }\end{array}$ & $\begin{array}{l}\text { Strategies of environmental } \\
\text { management including } \\
\text { policies, waste and sanitation } \\
\text { management, tree planting, } \\
\text { environmental education and } \\
\text { green labelling that aiming at } \\
\text { conserving the crocodile } \\
\text { ponds as tourism resources }\end{array}$ & $\begin{array}{l}\text { Tree planting } \\
\text { Conservation policies } \\
\text { Waste and } \\
\text { sanitation } \\
\text { management } \\
\text { Simple infrastructure } \\
\text { Environment and } \\
\text { sanitation education }\end{array}$ & $\begin{array}{l}\text { Drying up of the ponds } \\
\text { Silted ponds not dredged } \\
\text { Animal excreta in water } \\
\text { cause stingy smell } \\
\text { No environmental } \\
\text { labels } \\
\text { Unobserved carrying } \\
\text { capacity of ponds }\end{array}$ \\
\hline $\begin{array}{l}\text { Socio-cultural } \\
\text { Sustainability }\end{array}$ & $\begin{array}{l}\text { Activities that promote local } \\
\text { social and cultural values and } \\
\text { tourist interests. Such } \\
\text { activities also include human } \\
\text { development and training } \\
\text { workshops, community } \\
\text { integration, social cohesion, } \\
\text { and equity. }\end{array}$ & $\begin{array}{l}\text { Respect for social } \\
\text { and cultural values } \\
\text { and tourist interests } \\
\text { Social cohesion } \\
\text { Capacity develppment } \\
\text { of employees. } \\
\text { Infrastructural } \\
\text { development }\end{array}$ & $\begin{array}{l}\text { Tendency for the local } \\
\text { youth to adopt foreign } \\
\text { lifestyles due to } \\
\text { interaction with the } \\
\text { tourists } \\
\text { Tendency for some } \\
\text { children to engage in } \\
\text { income earning activities }\end{array}$ \\
\hline
\end{tabular}

Tourism activities are regarded as sustainable community-based when they integrate into local economic activities. This was clear in the results as tourism activities supports agriculture and domestic activities of the of local people. However, the use of the ponds by animals suggests a potential conflict as excreta of the animals causes bad scent and pollutes the water. The tourism regulation policies that prohibit cattle and donkeys from entering the water suggest a sign of potential conflict. Environmental sustainability is an essential 
element of community-based ecotourism development. Environmentally sensitive tourism practices respect ecological maintenance, waste and sanitation management, conservation practices, environmental education and monitoring of tourist numbers to ensure that carrying capacity of the environment is not exceeded. Tourism activities in Paga have some of these characteristics. The tourism infrastructure in the community is undeveloped and has no huge buildings. Community-based tourism infrastructure is usually in small scale. Efficient infrastructure is important for sustainable tourism practices. From the tourist comments, it is obvious that the infrastructure at the pond was not efficient. The inefficient infrastructure in Paga confirms the findings of Yankholmes \& Akyeampong (2010) for tourism infrastructure in Ghana is generally poor. Inefficient infrastructure does not retain tourists in tourism destination communities.

Sustainability of the tourism resources is important community-based tourism principle. The two experience droughts and siltation that keep lowering the water levels. The savannah dry climatic conditions are a threat to sustainability of tourism in the community. Social cohesion is crucial for sustainable community-based ecotourism. The Tourism Development Committee coordinates tourism stakeholders in Paga. This finding confirms Briedenhann \& Wickens (2004) assertion that tourism stakeholders in South Africa have to work collaboratively towards sustainable community-based tourism development. Social cohesion is good platform to sensitise community members for tourism development. Empowerment of the local people to participate in the tourism industry also fits into sustainable community-based ecotourism development guidelines. Sustainable tourism integrates the local people into tourism sector by giving them relevant training and education in Paga to be able to work efficiently (Dangi \& Jamal, 2016). Social justice and equity issues consider gender inclusion and fair share of proceed from tourism in the community. Revenue from tourism was used to build a kindergarten in the community. Sustainable tourism practices should consider the needs of the community people (Coria \& Calfucura, 2012; Das \& Chatterjee, 2015). Cusack \& Dixon (2006) also acknowledge that education and training workshops for local youth in tourism destinations give skills to be able to assess employment opportunities in the tourism sector. Tourism is labour intensive and an avenue for employing unskilled and semi-skilled labour. These authors also explain that retail trade in the tourism sector in southern Africa is dominated by women. The research findings suggest that record keeping is poor and statistics are inconsistent. The research indicated tourism in the community is informal and it is at a developing stage. Taking precautionary measures on the challenges facing tourism development can contribute to developing tourism in the locality into a sustainable community-based tourism.

\section{POLICY RECOMMENDATIONS FOR SUSTAINABLE COMMUNITY- BASED ECOTOURISM}

1. There is need for conservation and protection of the crocodile ponds. This can take several approaches including dredging and creation of buffer zones to reduce pollution and unwanted use of the ponds.

2. Environmental education and green labels at the ponds should be intensified to reduce indiscriminate waste disposal and environmental degradation.

3. Tourism infrastructure should be improved to provide satisfactory services.

4. Sustainable tourism development requires support from the stakeholders of government and other organisations.

\section{LIMITATIONS AND RECOMMENDATIONS FOR FUTURE RESEARCH}

This research was a single case and focused on the in-depth understanding and analysis of tourism of Paga crocodile ponds. The findings should be used without generalisation. The sample size was limited to key players in tourism management and 
did not include the views of all individuals from the community. Future research on sustainability of ponds should be detailed involving quantitative and qualitative methods to seek large sample size from the community.

\section{CONCLUSION}

This research was set to analyse stakeholder views on tourism characteristics and organisation at the Paga crocodile ponds from a sustainable community-based ecotourism framework, referring to the economic, environmental, cultural and social impacts of tourism in the community. These characteristics of tourism have been analysed and indicated that tourism in the community is managed by local traditional authorities and community elders with little involvement of government and corporate entities. Tourism is in its development stage and have benefits for the Paga community. To advance tourism development to a sustainable community-based ecotourism, there is need for other stakeholders from government, private sector, non-governmental and individuals to contribute to the efforts of traditional authorities to improve the management and infrastructure of tourism in the community. The crocodile ponds are getting silted and their sustainability as well as record keeping are a potential challenge to sustainable community-based ecotourism development in the community.

\section{Aknowlegments}

This paper is extracted from my master's research submitted to Geography Department, Brock University, Canada. I acknowledge the Paga community in Ghana for supporting this research with data. The author declares that the research followed research ethics.

\section{REFERENCES}

Acquah, E., Nsor, C. A., Arthur, E. K. \& Boadi, E. (2017). The socio-cultural impact of ecotourism on parkadjacent communities in Ghana. African Journal of Hospitality, Tourism and Leisure, 6(2), 1-14.

Amuquandoh, E. F. (2010). Lay concepts of tourism in Bosomtwe Basin, Ghana. Annals of Tourism Research, 37(1), 34-51.

Appiah-Opoku, S. (2007). Indigenous beliefs and environmental stewardship: A rural Ghana experience. Journal of Cultural Geography, 24(2), 79-98.

Asiedu, A. B. (2002). Making ecotourism more supportive of rural development in Ghana. West African Journal of Applied Ecology, 3, 1-16.

Baral, N. (2013). Evaluation and resilience of ecotourism in the Annapurna Conservation Area, Nepal, Environmental Conservation, 41(1), 84-92.

Boo, E. (1990). Ecotourism: The potentials and pitfalls, Volumes 1 and 2. World Wide Fund for Nature, Washington, DC.

Briedenhann, J. \& Wickens, E. (2004). Tourism routes as a tool for the economic development of rural areas vibrant hope or impossible dream? Tourism Management, 25, 71-79.

Cappucci, M. (2016). Indigenous tourism in the Amazon region of Suriname: actions to preserve authenticity and natural resources. Geojournal Of Tourism and Geosites, 1(17), 47-56.

Cetinkaya, M. Y. \& Oter, Z. (2016). Role of tour guides on tourist satisfaction level in guided tours and impact on revisiting intention: A research in Istanbul. European Journal of Tourism, Hospitality and Recreation, 7(1), 40-54.

Cobbinah, P. B. (2015). Contextualising the meaning of ecotourism. Tourism Management Perspectives, 16, $179-189$.

Cobbinah, P. B., Black, R. \& Thwaites, R. (2015). Ecotourism implementation in the Kakum Conservation Area, Ghana: Administrative framework and local community experiences. Journal of Ecotourism, 14(23), 223-242.

Cook, I. \& Crang, M. (2007). Doing ethnographies. London, Sage Publications.

Coria, J. \& Calfucura, E. (2012). Ecotourism and the development of indigenous communities: The good, the bad, and the ugly. Ecological Economics, 73(15), 47-55.

Cusack, D. \& Dixon, L. (2006). Community-based ecotourism and sustainability. Journal of Sustainable Forestry, 22, 157-182.

Dangi, T. B. \& Jamal, T. (2016). An integrated approach to sustainable community-based tourism. Sustainability, 8(5), 475 .

Das, M. \& Chatterjee, B. (2015). Ecotourism: A panacea or a predicament? Tourism Management Perspectives, 14, 3-16.

Eshun, G. \& Tagoe-Darko, E. (2015). Ecotourism development in Ghana: A postcolonial analysis. Development Southern Africa, DOI: 10.1080/0376835X.2015.1020218.

Eshun, G. \& Tonto, J.N.P. (2014). Community-based ecotourism: Its socio-economic impacts at Boabeng-Fiema Monkey Sanctuary, Ghana. Bulletin of Geography Socio-economic Series, 26, 67-81.

Fennell, D. A. (2001). A content analysis of ecotourism definitions. Current Issues in Tourism, 4(5), 403-421. 
Fuschi, M., \& Evangelista, V. (2017). The rural tourism challenge in Pescara's Hilly Landscape, Italy: Awareness, integration, sustainability. 2(20), 272-281.

Hall, C. M. (2013). Framing tourism geography: Notes from the underground. Annals of Tourism Research, 43, 601-623.

John-Parson, D. S. (1958). Legends of northern Ghana. Longman, Green, London.

Jovanović, S. \& Ilić, I. (2016). Infrastructure as important determinant of tourism development in the countries of Southeast Europe. Ecoforum, 5(1)8, 288-294.

Kuqi, B. (2018). Theoretical approach concerning the development of sustainable tourism as tourist destination in Kosovo. Geojournal Of Tourism and Geosites, 22(2), 489-496.

Lee, T. H. (2013). Influence analysis of community resident support for sustainable tourism development. Tourism Management, 34(1), 37-46.

Mugizi, F., J. Ayorekire, J. \& Obua, J. (2018). Contribution of tourism to rural community livelihoods in the Murchison Falls Conservation Area, Uganda. African Journal of Hospitality, Tourism and Leisure, 7(1), 1-17.

Odede, F. Z. A., Hayombe, P. O. \& Agong, S. G. (2015). Ecotourism for community empowerment and social inclusion: The case of Abindu Sacred site in Kisumu County, Kenya. Journal of Economics and Sustainable Development, 6(14), 2015.

Ojeda, D. (2012) Green pretexts: Ecotourism, neoliberal conservation and land grabbing in Tayrona National Natural Park, Colombia. Journal of Peasant Studies, 39(2), 357-375.

Richards, G. \& Hall, D. (2000). The community: A sustainable concept in tourism development? In: Grek

Richards \& Derek Hall (eds.) Tourism and Sustainable Community Development. London, Routledge: Taylor and Francis Group, pp.1-14.

Rim-Rukeh, A. G., Irerhievwie, G. \& Agbozu, I. E. (2013). Traditional beliefs and conservation of natural resources: Evidences from selected communities in Delta State, Nigeria. International Journal of Biodiversity and Conservation, 5(7), 426-432.

Rogerson, M.C. (2007). Reviewing Africa in the global tourism economy Development of Southern Africa, 24(3), 361-379.

Rogerson, M. C. (2014). The uneven geography of tourism in South Africa, African Journal of Hospitality, Tourism and Leisure 3(1), 1-15.

Rylance, A. (2008). Local economic development in Mozambique: An assessment of the implementation of tourism policy as a means to promote local economies ${ }^{\text {ee }}$ In: Anna Spenceley (ed.) Responsible Tourism: Critical Issues for Conservation and Development, pp.27- 40.

Scheyvens, R. (1999). Ecotourism and the empowerment of local communities. Tourism Management, 20, $245-249$.

Spenceley, A. (2007). Responsible tourism practices by South African Tour Operators. International Centre for Responsible Tourism, South Africa.

Spenceley, A. (2008). Impacts of wildlife tourism on rural livelihoods in Southern Africa. In: Anna Spenceley (ed.) Responsible Tourism, Critical Issues for Conservation and Development, London and Sterling, VA, pp. 159-183.

Telfer, J. D. \& Sharpley, R. (2008). Tourism and development in the developing world. London and New York, Routledge Taylor \& Francis Group.

Tichaawa, T.M. \& Mhlanga, O. (2015). Community perceptions of a community-based tourism project: A case study of the CAMPFIRE programme in Zimbabwe. African Journal for Physical, Health Education, Recreation and Dance, Supplement 1, 55-67.

Urry, J. (2002). The tourist gaze. Second Edition. London, Sage Publication Ltd.

Wearing, S. \& Neil, J. (1999). Ecotourism impacts, potentials and possibilities. Oxford, Elsevier Butterworth-Heinemann.

Weaver, D. (2009). Ecotourism. Second Edition. John Wiley and Sons Australia, Ltd. Milton.

Williams, S. (2009). Tourism geography: New synthesis. Second Edition. London and New York, Routledge: Taylor and Francis Group.

Woldu, M. G. (2018). Community based tourism in Lake Tana growth corridor of the Amhara region of Ethiopia: The missing link among stakeholders and implications to tourism industry, Cogent Social Sciences, 4, 1-15.

Yankholmes, B. K. A. \& Akyeampong, A. Oheneba. (2010). Tourists perceptions of heritage tourism development in Danish-Osu, Ghana. International Journal of Tourism Research, 12, 603-616.

Yin, R. K. (2009). Case study research, design and methods $4^{\text {th }}$ Edition. Los Angeles, Sage.

*** Brundtland Report (1987). Our common future. World Commission on Environment and Development (WCED). Oxford, Oxford University Press.

*** Kasena-Nankana West District Assembly. (2009). The district profile, Local Government Department, Kasena-Nankana West District Assembly, Paga, Ghana.

*** The International Ecotourism Society (TIES) (2018). What is ecotourism. The International Ecotourism Society.

*** World Travel \& Tourism Council (WTTC) (2015). Travel and tourism economic impact, Ghana. London, The Authority on World Travel \& Tourism Council.

*** World Travel \& Tourism Council (WTTC) (2018). Travel and tourism economic impact, Ghana. London, The Authority on World Travel \& Tourism Council.

Submitted:

23.10.2018
Revised:

o8.04.2019
Accepted and published online 11.04.2019 